\title{
REPRESENTASI PROFESI PUSTAKAWAN DAN FUNGSI PERPUSTAKAAN (ANALISIS SEMIOTIKA ROLAND BARTHES TERHADAP NOVEL BETA TESTING)
}

\author{
Ina Kenacna Putri \\ Pascasarjana Interdisciplinary Islamuc Study \\ Konsentrasi Ilmu Perpustakaan dan Informasi UIN Sunan Kalijaga \\ Jl. Marsda Adisucipto, Yogyakarta. \\ inakencanaputri@gmail.com
}

Dr. Sri Rohayati Zulaikha, S.Ag., SS., M.Si.

UIN Sunan Kalijaga Jl. Marsda Adisucipto, Yogyakarta.

sri.zulaikha@uin-suka.ac.id

\footnotetext{
Received : 18 July 2021

Revised : 29 September 2021

Accepted : 05 October 2021

DOI :
}

\begin{abstract}
Abstarct
Novel with the tittle Beta Testing is a novel written by an authorl with a pen name Mooseboo and published in 2019. The aim of this research is to look howa novel represented a Libarian as Profession and the function of library. This research using the representation theory as a main theory and used to find and see how a librarian and function of library portrayed. And then the semiotics theory was used as analysis to find a symbols, the meaning and the messages that representing a profession of librarian and the function of library inside this novel. The method used in this research is collecting words or dialogs and then dissected using Roland Barthess semiotics theory. Conclusion that was find from this research is that profession of librarian was represented as, 1) Librarian as helper, 2)Librarian as a educator, 3) Libaraian as a discussion partner, 4) Librarian as a consultant, 5) Librarian as information fasilitator. While the representation of function of library was found ou as, 1) Libarary as a storage collection and 2) Library as education facilities.

Keywords: Representation, Librarian, Roland Barthes Semiotics.
\end{abstract}

\section{PENDAHULUAN}

Potret-potret tentang kehidupan masyarakat sebagai seorang makhluk sosial senantiasa hadir setiap waktu, setiap tempat bahkan pada setiap saat tidak peduli kondisinya. Kepingan-kepingan kehidupa sosial yang senantiasa hadir di masyarakat tersebut seolah-olah seperti puzzel yang terlihat nampak terlalu jelas untuk sekedar diabaikan tanpa sedikitpun perhatian publik. Sebagai salah satu bagian dari tatanan kehidupan sosial, maka pean manusia dalam tatanan tersebut acap kali tidak hanya berperan sebagai penonton saja, akan tetapi turut menjadi bagian dalam sebuah kehidupan sosial. Keberadaan perpustakaan lahir dari bagian kehidupan sosial masyarakat yang selalu berkembang dan berubah dengan cepat.

Perpustakaan yang merupakan potret dari realitas kehiudpan masyarakat yang membutuhkan informasi kini keberadaannya kian dipertimbangkan. Namun perpustakaan yang lahir sebagai sebentuk pusat informasi bagi masyarakat representasinya dalam 
pandangan masyarakat masih kerap kali identik dengan bangunan tua, rak penuh buku dan gelap. Sebuah penelitian yang dilakukan oleh (Devi dan Slamet, 2016), menghasilkan bentuk penggambaran bagaimana stereotipe perpustakaan dalam pandangan penulis cerita. Pandangan para penulis ini yang kemudian digambarkan dalam sebuah cerita lalu membentuk representasi perpustakaan dalam ranah negatif, seterotipe yang digambarkan oleh para penulis cerita dalam laman fanfiction.net ini berkisar pada perpustakaan sebagai suatu tempat yang hening, sepi gelap dan misterius, yang kemudian digambarkan sebagai suatu lokasi dimana para siswa membolos, selain itu juga digunakan sebagai lokasi untuk tidur karena suasananya sepi. Namun pemaknaan negatifnya tidak hanya sebatas itu, ada juga perpustakaan digambarkan sebagai tempat yang menyeramkan karena suram, dan digambarkan sebagai tempat yang berhantu. Dari pemakanaan tersebut lahirlah penggambaran perpustakaan sebagai tempa melakukan asusila, dimana dalam sebuah cerita yang ditulis nyaris tidak ada pemaknaan positif terhadap perpustakaan.

Padahal makna perpustakaan sendiri yang sesungguhnya dapat dianggap sangat kompleks, Hasugian, mencoba menjelaskan makna dari sebuah perpustakaan dengan ringkas seperti, "Perpustakaan adalah koleksi atau sekumpulan koleksi buku atau bahan lainya yang diorganisasikan dan dipelihara untuk penggunaan atau keperluan (membaca, konsultasi, belajar, meneliti), dikelola oleh pustakawan dan staf terlatih lainya dalam rangka menyediakan layanan untuk memenuhi kebutuhan pengguna"(Hasugian, 2009, 70). Selain stereotipe yang negatif tentang perpustakaan, maka staf yang bekerja di perpustakaan atau pustakawan juga tidak lepas dari setereotipe itu.

Pada studi yang dilakukan oleh (Mayesti, 2018), atas film-film indonesia era 2000-an, ditemukan stereotip bagaimana citra dan gambaran seorang pustakawan perempuan di mata masyarakat yang merupakan produser film. Dari hasil studi tersebut, diperoleh hasil bahwa ada citra stereotip terhadap karakteristik visual profesi pustakawan perempuan, hal ini dimulai dari usia, gaya busana hingga tata rambut. Dari stereotip itu lahirlah pemaknaan bahwa profesi pustakawan merupakan profesi yang lebih cocok bagi perempuan tua yang memiliki prefrensi busana formal dan konservatifserta pilihan tatanan rambut yang ketinggalan zaman. Dari aspek sifat dan perilakunya pun, terdapat penggambaran negatif, yaitu pustakawan digambarkan sebagai sosok yang pasif, kaku, nampak pemaran dan juga tertib. Namun, ada juga gambaran yang cukup positif, yaitu pustakawan digambarkan sebagai seseorang yang ramah, pintar, penolong bahkan digambarkan juga melanggar aturan. 
Fenomena-fenomena yang terjadi di masyarakat tentang profesi pustakawan dan perpustakaan menjadi suatu hal yang menarik dan juga sangat layak untuk diangkat dan diteliti dalam sebuah bentuk penelitian ilmiah. Profesi pustakawan dan juga perpustakaan seolah-olah selalu menjadi sebuah kombinasi yang buruk dan negatif, dan hal ini pada akhirnya menyebabkan setiap orang yang memotert potret profesi pustakawan dan juga perpustakaan tidak dapat diajuhkan dari sisi-sisi yang mencerminkan kenegatifan. Untuk mengugah rasa dan memunculkan kesadaran akan kenyataan sebuah profesi dan sebuah lokasi, sudah banyak upaya yang dilakukan, baik melalui kegiatan sosial, kekuatan-kekuatan akdemik dan akademisi, organisasi-organisasi non pemerintah, bahkan hingga para seniman. Salah satu karya menarik dilakukan oleh penulis dengan nama pena Mooseboo di tengah pesatnya perkembangan media teknologi, komunikasi, dan informasi dengan menyajikan representasi dari realitas kehidupan seorang pustakawan dan perpustakaan melalui novelnya yang berjudul Beta Testing.

Karya novel Beta Testing ini menyajikan realitas profesi pustakawan melalui kisah seorang wanita yang memiliki probelamtika kehidpannya. Novel ini pada dialognya menyajikan beragam permasalahan yang di hadapi oleh perpustakaan dan juga psuatakawan saat ini, novel setebal 342 (tiga ratus empat puluh dua) halaman ini mencoba menggambarkan profesi pustakawan dengan menggambarkannya bekerja pada salah satu perpustakaan swasta umum dibilangan daerah Jakarta. Tidak dapat dipungkiri bahwa hadirnya dan keberadaan akan sebuah karya seni di tengah masyarakat dapat mempunyai makna yang unik sebagai bagain dari media komunikasi bagi masyarakat. Novel sendiri dipandang efektif dalam menyebarluaska sebuah ide ataupun gagasan bagi para masyarakat. Novel sebagai suatu perwujudan sebuah representasi sosial masyarakat telah mencoba membentuk dan menyampaikan kembali realitas yang ada di masyarakat melaui simbol-simbol, tanda-tanda, atau bahkan ikon-ikon yang kemudian menjadi sebuah hal yang sangat butuh untuk ditafsirkan. Representasi permasalahan yang hadir dalam novel perpustakaan ini dapat berupa penggambaran negatif yang kelewat berlebihan terhadap profesi pustakawan dan juga perpustakaan, oleh karena itu penulis merasa tertarik untuk melakukan pembedahan terhadap novel Beta Testing karya dari Mooseboo tersebut.

\section{METODE}

Metode yang digunakan dalam penelitian ini ialah dengan menggunakan studi literatur, dimana studi literatur merupakan suatu teknik pengumpulan data dengan 
menggunakan bahan - bahan seperti literatur atau buku - buku. Sedangkan penelitian ini merupakan penelitian dengan pendekatan kualitatif dengan menggunakan analisis semiotika. Analisis semiotika yang digunakan dalam penelitian ini merupakan analisis semiotika Roland Brathes. Semiotika sendiri merupakan suatu ilmu yang mempelajari sistem tanda atau teori tentang pemberian sebuah tanda. Semiotika sendiri meliputi tanda-tanda visual dan verbal (seluruh tanda atau sinyal yang dapat diakses dan dapat diterima oleh seluruh indera yang kita miliki). Semiotika merupakan studi mengenai tanda (sign) dan simbol yang merupakan sebuah tradisi pentin dalam pemikiran tradisi komunikasi. Semiotika mencakup teori utama mengenai bagaimana tanda mewakili suatu objek ide, situasi, keadaan, perasaan, dan sebagainya yang berada diluardiri. Studi semiotika ini tidak hanya memberikan jalan atau cara dalam mempelajarai komunikasi, namun juga memiliki sebuah efek besar pada setiap aspek (perspektif) yang digunakan dalam teori komunikasi (Morissan, 2013, 32).

Metode analisis semiotik bersifat lebih interpretif-kualitatif, yaitu suatu metode yang memfokuskan dirinya pada tanda dan teks sebagai objek kajiannya, serta bagaimana seorang peneliti menfsirkan dan memahami kode di balik suatu tanda dan teks tersebut. Roland Barthes sebagai pencetus analisis semotika miliknya, juga dikenal sebagai salah seorang pemikir strukturalis yang rajin dalam mempraktikkan model linguistik dan semiologi saussure. Roland Barthes meneruskan pemikiran milik Saussure dengan menekankan interaksi antara teks dengan pengalaman personal dan kultural penggunanya, lalu interaksi antara konvensi dalam suatu teks dengan konvensi yang dialami dan diharapkan oleh penggunanya. Pemikiran Roland Barthes ini kemudian dikenal dengan "order of signification”. Tatanan penandaan (order of signification) seperti dalam (Kriyantono, 2012, 272-273), terdiri sebagai:

a. Denotasi merupakan deskripsi dasar, makna kamus dari suatu kata atau terminologi atau pun objek (literal meaning of a term or object).

b. Konotasi merupakan makna-makna kultural yang melekat pada suatu terminologi (the cultural meaning that become attached to a term).

c. Metafora merupakan suatu alat untuk mengkomunikasikan sebuah analogi atau suatu perumpamaan yang didasarkan pada sebuah identitas.

d. Simili merupakan sebuah subkategori metafora dengan menggunakan kata-kata "seperti". 
e. Metomini merupakan sebuah cara mengomunikasikan dengan asosiasi yang dibuat dengan cara menghubungkan sesuatu yang telah kita ketahui dengan sesuatu yang lain.

f. Synechoche adalah suatu subkategori meteomini yang memberikan makna "keseluruhan" atau "sebaliknya".

g. Intertextual merupakan hubungan antarteks saling bertukar satu dengan yang lain, secara sadar maupun tidak sadar.

\section{TINJAUAN LITERATUR}

Stuart Hall dalam bukunya yang berjudul Representation : Cultural Representation and Signifyig Practices menyatakan bahwa "Representation connects meaning and language to culture. Representation is an essential part of the process by which meaning is produced and exchanged between members of culture”. Yang artinya melalui representasi maka suatu makna diproduksi dan dipertukarkan antar anggota masyarakat. Sehingga secara singkatnya, representasi sendiri ialah suatu cara untuk memproduksi makna.Representasi juga merupakan hubungan antara konsepkonsep pikiran dan bahasa yang memungkinkan seorang pembaca menunjuk pada dunia yang sesungguhnya dari suatu objek, realitas, atau pada dunia imajiner tentang objek fiktif manusia ataupun peristiwa. Jadi, representasi merupakan proses di mana suatu kelompok budaya menggunakan bahasa untuk memproduksi makna (Hall, 2003, 17).

Dalam merepresentasikan suatu hal, seperti profesi pustakawan dan fungsi perpustakaan maka haruslah dimengerti terlebih dahulu apakah sesungguhnya makna dari profesi pustakawan dan fungsi perpustakaan tersebut. Pustakawan sendiri dalam (Qalyubi, 2007,4), dijabarkan sebagai suatu profesi dimana orang tersebut bekerja di perpustakaan atau lembaga sejenisnya dan memiliki pendidikan secara formal (di Indonesia kriteria pendidikan minimal D-2 dalam bidang ilmu perpustakaan, dokumentasi dan informasi).Profesi sendiri terkait erat dengan pekerjaan, tetapi memiliki arti lebih dari sekedar pekerjaan. Profesi sendiri umumnya sering dinayatakan sebagai pekerjaan yang membutuhkan keahlian dan latar belakang pendidikan/pelatihan khusus yang sesuai dengan bidang profesi tersebut. Dalam kaitannya dengan makna profesi pustakawan (Heriyanto dkk, 2013, 150) mengemukakan ada delapan makna profesi perpustakaan yang diperoleh dari 
penelitiaannya dan dijabarkan sebagai berikut, 1) Pustakawan sebagai penolong. Dimana profesi pustakawan sifatnya adalah memberikan pelayanan kepada pengguna perpustakaan, maka salah satu makna dari profesi pustakawan adalah profesi yang bertujuan menolong orang dalam menemukan informasi yang dibutuhkan. 2 ) Pustakawan sebagai pendidik. Ialah bahwasanya profesi ini tidak hanya terbatas pada mengumpulkan, mengolah, dan menyebarkan informasi. Tetapi pustakawan juga berperan sebagai pendidik, mengajarkan seseorang dari kondisi awal tidak tahu menjadi tahu. 3) Pustakawan sebagai teman diskusi. Seorang pustakawan dengan pengetahuannya yang luas dan dengan keterampilan komunikasi yang baik, dapat menjadi teman berdiskusi bagi para mahasiswa. 4) Pustakawan sebagai konsultan. Pustakawan dengan bekal pengetahuan yang luas, mampu untuk mempelajari berbagai hal dengan cepat, dan memiliki kemampuan analisis dan evaluasi yang baik, juga dapat berperan sebagai konsultan. 5) Pustakawan sebagai pembimbing. Pustakawan kerapkali berperan juga sebagai pembimbing mahasiswa yang sedang mengerjakan skripsi/tugas akhir, walaupun tidak secara formal. 6) Pustakawan sebagai manajer informasi. Pustakawan dituntut lebih mampu dalam menentukan materi apa yang akan dilanggan atau dikoleksi oleh perpustakaan, selain itu pula pustakawan perlu mampu untuk memperkirakan apa yang menjadi kebutuhan pengguna, dan menyediakan koleksi-koleksi yang memang dibutuhkan oleh pengguna. 7) Pustakawan sebagai fasilitator informasi. Pustakawan pun bertanggungjawab agar informasi-informasi tersebut dapat sampai kepada pengguna yang membutuhkan. Istilah fasilitator pun mengandung makna bahwa pustakawan berperan aktif sebagai agen informasi. 8) Pustakawan sebagai profesi yang menjanjikan. Profesi pustakawan menjanjikan karena keberadaan dan perannya akan selalu dibutuhkan, bahkan dengan datangnya era informasi seperti saat ini, profesi pustakawan semakin dibutuhkan.Juga ruang lingkup kerja pustakawan pun berkembang seiring dengan perkembangan waktu.

Sedangkan fungsi perpustakaan sendiri memiliki beberapa makna, (Trimo, 1992, 2), menyatakan bahwa terdapat empat macam fungsi peprustakaan yang dapat dikategorikan sebagai, 1)suatu pusat atau jantung dari seluruh program pendidikan suatu institusi yang bersangkutan. Perpustakaan harus mampu membantu dan dapat menjadi pusat kegiatan akademis lembaganya. 2) pusat alat-alat, bahan-bahan pengajaran atau instructional material center.3) Clearing house bagi bagi semua 
penerbitan dari dan tentang daerahnya ataupun dalam bidang pengetahuan tertentu. 4)

Social center dan pusat kegaitan kultural dalam masyarakat setempat. Makna ini kemudian diperluas oleh (Hasugian, 2009, 82), dimana dinyatakan bahwa fungsi perpustakaan selalu dikaitkan dengan jenis perpustakaan dan misi yang diembannya. Perpustakaan umum tentunya memiliki fungsi yang berbeda dengan perpustakaan khusus karena misi yang diemban berbeda. Namun secara umum fungsi perpustakaan dibagi dalam enam kategori yaitu, penyimpanan, pendidikan, penelitian, informasi, kultural dan rekreasi.

\section{HASIL DAN PEMBAHASAN}

Apabila representasi dikaitkan dengan suatu karya sastra misalnya novel, maka representasi dalam karya sastra sendiri ialah suatu penggambaran karya sastra terhadap suatu fenomena sosial, dan dilakukan melalui pengarang sebagai kreatornya. Representasi yang digunakan dalam mengkaji novel erat kaitannya dengan fungsi novel itu sendiri sebagai salah satu sarana merepresentasikan informasi. Novel sendiri merupakan salah satu media yang mengkontruksi apa yang terjadi dan menjadi suatu keyakinan suatu masyarakat atau komunitas tentang nilai-nilai yang ada pada komunitas tersebut. Seperti halnya dalam novel Beta Testing karya Mooseboo ini. Novel ini digunakan sebagai media untuk memahami dan merepresentasikan bagaimana peran seorang pustakawan dimana buku ini ditulis. Pada penggambaran pustakawannya sendiri dapat dilihat dari naskah dan dialog-dialog antar tokohnya. Dengan memahami makna serta pesan-pesan dalam novel Beta Testing ini maka dapat diketahui aspek apa sajakah yang disampaikan oleh penulisnya.

\section{Representasi Profesi Pustakawan}

Bentuk penggambaran profesi pustakawan dalam novel Beta Testing ini bisa dikatakan agak berbeda dengan realita pustakawan dan perpustakaan yang sesungguhnya. Dalam konteks ini, novel Beta Testing ini memandang bahwa profesi pustakawan hanya terlihat menonjol dalam beberapa bidang saja. Bahkan dalam beberapa naskah awal, pustakawan awalnya digambarkan sebagai seorang perempuan antik atau perempuan hitam putih.

\section{Kutipan Dialog 1}

"Kenapa, ya?" Perempuan berkemeja putih dengan renda dibagian depan serta rok midi bercorak kotak-kotak itu mengawasi Pange.

"Saya Cuma mau antar buku dari Brian Maxey, NCVision. Gedung sebelah."

"Untuk acara donor buku?" tanya perempuan itu lagi, sambil menyiapkan sesuatu di mejanya. "Mas...?" 
"Pangeran. Panggil aja Pange."

Perempuan itu tersenyum, lantas menyerahkan selembar formulir ke depan Pange. Sambil menarik kertas formulir diatas meja, Pange memandangi si perempuan hitam-putih itu, seakan curiga dengan senyumnya barusan.

"Isi datanya dulu di situ," tunjuk perempuan itu. "Ini bukunya? Saya bawa ke dalam, ya." (Moosebo, 2019, 16).

Tabel 1.1 (Penggambaran makna denotasi dan konotasi)

\begin{tabular}{|c|c|c|c|}
\hline \multirow[b]{2}{*}{ Denotasi } & Signifier & Signified & \\
\hline & Kutipan dialog halaman 16 & $\begin{array}{l}\text { Interpretasi / } \\
\text { deskripsi }\end{array}$ & \\
\hline \multirow{4}{*}{ Konotasi } & \multicolumn{2}{|l|}{ Signifier } & \\
\hline & \multirow{2}{*}{\multicolumn{2}{|c|}{ Pustakawan memberikan bantuan }} & Signified \\
\hline & & & $\begin{array}{l}\text { Pemustaka } \\
\text { pada posisi } \\
\text { yang dibantu. }\end{array}$ \\
\hline & \multicolumn{3}{|c|}{ Connotative sign: Pustakawan adalah helper (penolong) } \\
\hline
\end{tabular}

Dari kutipan kalimat diatas tersebut, pustakawan berada diposisi sebagai profesi yang membantu orang-orang yang datang ke perpustakaan atau disebut sebagai "pemustaka" meskipun dengan kepentingan yang berbeda-beda. Penggambaran itu didukung dengan penjelasan tentang tujuan Pange dan arahan dari pustakawan yang membantunya. Pada kutipan yang dimulai dengan kalimat pertanyaan tersebut menunjukkan bahwa pustakawan senantiasa menanyakan kebutuhan tiap pemustaka yang datang ke perpustakaan. Lalu kalimat yang menyiratkan untuk melakukan pengisian formulir juga menunjukan penggambaran pustakawan yang membantu kepentingan pemustaka.

\section{Kutipan Dialog 2}

“Kamu ngapain?!” bentak Magda membuat tubuh Pange menyembul.

"Bantuin kamu ngerapiin."

"Kamu pikir kenapa disitu ada tulisan 'Buku yang sudah dibaca harap diletakkan di troli dan jangan ditempatkan ke dalam rak'?!' ketus Magda menarik buku dari tangan pange dengan tangan kiri, sedangkan tangan yang lain menunjuk tulisan berwarna kuning cerah yang terlihat mencolok di setiap rak.

Pange mengangkat kedua bahunya. "Biar kamu ada kerjaan?"

Sontak saja membuat Mmagda makin berang "Kamu tahu DDC? Dewey Decimal Classification? Tahu kenapa tiap buku punya nomor kayak gini?" tegur perempuan itu menunjuk label pada buku di tangannya.

Pange menggeleng. Magda mengerang kesal, lantas mendorong trolinya lagi meninggalkan Pange.

"100 Filsafat, 200 Agama, 300 Ilmu Sosial, dan seterusnya," jelas Magda tanpa diminta seraya menunjuk label panjang di buku. "Semua buku di perpustakaan dilabeli sesuai genre. Setelah itu dibagi lagi per-sub genrenya. 302.2 misalnya, untuk buku-buku komunikasi. Labelnya pun bisa jadi sepanjang ini.” (Mooseboo, 2019, 29).

"Buku yang disitu enggak ikut dirapihin?"

"Hasil wedding. Mau dimasukin ke kardus." 
"Weeding? Emang boleh buku perpus buat suvenir nikah?" Alih-alih menjawab, yang ditanya justru memandangi lelaki itu datar tanpa ekspresi.

"Wedding bukan wedding," koreksi Magda tajam sambil meminta Pange untuk bergeser agar troli yang dia dorng dapat lewat.. "Semacam penyiangan bahan pustaka. Kalau stock opname untuk periksa kelengkapan koleksi, weeding proses penarikannya."

Pange mengangguk-anggukan kepalanya paham, teringat obrolan mereka di NCVision waktu itu. "Koleksi yang ditarik lantas dibuang?"

"Beberapa dijual, dihibahkan, ke perpustakaan lain, atau dimusnahkan kalau isinya sudah enggak relevan atau udah enggak bermanfaat.” (Mooseboo, 2019, 101).

"Sayang banget ya, buku banyak kayak gini jarang yang baca."

Mata Magda mengedip lambat, mendengar kalimat Pange barusan. Dia sangsi kalimat tadi keluar dari mulut seorang Pange. Kepalanya lalu ikut berpindah ke arah yang sama dengan lelaki itu.

"Sebenernya buku-buku di sini udah banyak yang diubah jadi e-book dan bisa diakses via online, katanya biar orang bisa tetap akses dan baca. Tapi saya sendiri malah jadi sedih karena gara-gara itu orang malas ke sini., seperti kamu bilang pada akhirnya perpustakaan cuma jadi museum sejarah," terang Magda. "Disrupsi teknologi." (Mooseboo, 2019, 194).

Tabel 1.2(Penggambaran makna denotasi dan konotasi)

\begin{tabular}{|c|c|c|c|}
\hline \multirow[b]{2}{*}{ Denotasi } & Signifier & Signified & \\
\hline & $\begin{array}{l}\text { Kutipan dialog halaman } 29, \\
\text { 101, dan } 194 .\end{array}$ & $\begin{array}{l}\text { Interpretasi / } \\
\text { deskripsi }\end{array}$ & \\
\hline \multirow{4}{*}{ Konotasi } & \multicolumn{2}{|l|}{ Signifier } & \\
\hline & \multirow{2}{*}{\multicolumn{2}{|c|}{$\begin{array}{l}\text { Pustakawan sebagai seseorang yang } \\
\text { memberikan informasi yang belum diketahui } \\
\text { olah pemustaka. }\end{array}$}} & Signified \\
\hline & & & $\begin{array}{l}\text { Pemustaka } \\
\text { tidak } \\
\text { mengetahui } \\
\text { seluk beluk dan } \\
\text { informasi } \\
\text { tentang } \\
\text { perpustakaan. }\end{array}$ \\
\hline & \multicolumn{3}{|c|}{ Connotative sign: Pustakawan digambarkan sebagai pendidik. } \\
\hline
\end{tabular}

Dalam kutipan diatas tersebut, pustakawan digambarkan tengah memberikan informasi kepada pemustaka yang kurang mengetahui tentang hal-hal yang berkaitan dengan perpustakaan. Magda merepresentasikan pustakawan yang memberikan secuil informasi kepada Pange yang direpresentasikan sebagai pemustaka. Kutipan dialog halaman 29 diawali dengan kalimat yang menandakan pertanyaan terhadap hal yang hendak dilakukan oleh pemustaka. Dengan ketidaktahuannya pada dialog itu Pange sebagai pemustaka hendak membantu melakukan shelving buku, hingga pada akhirnya menyebabkan kekesalan Magda, dan berakhir dengan Magda sebagai pustakawan menjelaskan tentang informasi mengenai labeling dan klasifikasi buku yang ada di perpustakaan. Pada dialog selanjutnya Magda sebagai pustakawan menjelaskan bahwa tiap buku memiliki klasifikasi yang berbeda sesuai dengan kelasnya. 
Sedangkan kutipan dialog halaman 101, yang diawali dengan pernyataan terkait merapikan buku merepresentasikan tentang salah satu pekerjaan yang dilakukan pustakawan yaitu shelving. Pada dialog selanjutnya pustakawan mengatakan bahwa buku tersebut merupakan buku hasil dari penyiangan atau weeding, dimana umumnya buku yang di weeding sudah tidak relevan dengan kebutuhan perpustakaan saat ini. Pada dialog selanjutnya mengambarkan ketidaktahuan Pange sebagai pemustaka akan bedanya weeding dengan wedding, yang pada akhirnya membuat Magda menjelaskan makna weeding secara singkat kepada Pange. Kemudian hal ini menyebabkan Pange melontarkan pertanyaan akan kemana koleksi buku yang sudah diwedding tersebut, dan membuat Magda selaku pustakawan menjelaskan kebijakan wedding yang ada di perpsuatakaan. Dialog penjelasan Magda akan pengertian weeding tersebutlah yang merepresentasikan pustakawan sebagai pendidik yang memberi informasi.

Pada kutipan selanjutnya yaitu dialog pada halaman 194, kalimat dimulai dengan pernyataan Pange akan banyaknya buku di perpustakaan namun kurangnya minat masyarakat dalam membaca dan memanfaatkannya. Yang kemudian hal ini berlanjut pada penjelasan Magda akan hadirnya buku elektronik atau kerap disebut dengan e-book sebagai bagian dari kemajuan teknologi. Kemudian Magda juga mengemukakan bahwa ia sebagai pustakawan acap merasa sedih dengan kehadiran teknologi yang menyebabkan perpustakaan mulai ditinggalkan pemustaka, dan hal ini merupakan disrupsi teknologi. Penjelasan Magda mengenai e-book yang lahir agar peustaka dapat senantiasa mengakses dimanapun dan kapanpun inilah yang merupakan penanda peran profesi pustakawan dalam mendidik.

\section{Kutipan Dialog 3}

"So, balik lagi ke teknologi. Emang menurut kamu teknologi yang punya substansi itu kayak gimana?"

"Kamu tau Alexandiria Bibliotecha?"

Kepala Pange kembali menoleh kepada Magda, kemudian menggeleng.

"Itu perpustakaan pertama di dunia yang menyimpan ribuan perkamen tentang ilmu pengetahuandi zaman dulu," cerita Magda meletakkan buk terakhir ke dalam rak.

"Karena di masa itu ilmu pengetahuan masih mahal, enggak semua orang punya buku atau perkamen. Dari mulai Starbo, pakar Geografi Yunani kuno yang udah percaya kalau bumi itu bulat, sampai Heron, pencipta automata atau robot pertamaa. Semua perkamen dan ilmunya ada disitu."

Kepala Pange mengangguk paham. Dia pernah mendengar soal Heron dan salah satu automata buatannya, pembuka dan penutup pintu otomatis.

"Jadi, kalau menurut saya teknologi yang bersubtansi itu seperti Perpustakaan Alexandira. Yang dengan kemunculannya, bawa hawa baru buat peradaban juga untuk imu pengetahuan." 
"Berat," sahut Pange. "Kalau kamu nganggep yang bersubtansi itu loncatan besar, menurut saya sulit untuk zaman sekarang”.

"Kata siapa? Saya masih bisa lihat itu di Charles Babbage, Steve Job, atau Mark Zuckerberg," sebut Magda enteng. "Bukannya kalau tanpa mereka enggak akan ada istilah dunia digital? Cuma, untuk game -“

"Oke, I get it," potong Pange.

"Maaf, kamu kan tanya, dan jawaban saya ya itu," celetuk Magda tanpa basabasi.(Mooseboo, 2019, 30-31).

"Kenapa enggak coba bikin something yang anak muda banget? Game room, misalnya. Di luar negeri udah ada loh perpus yang nyediain game room buat pengunjung. Yah, walaupun saya enggak yakin sih disini efektif."

"Sebenernya, dulu sempet ada wacana renovasi lantai dua buat dijadiin tempat ramah anak," tutur Magda terkesan sebal. "Rencanaya food court di atas dibagi dua area. Satu untuk food court. Sisanya area refreshing kayak tempat untuk board game, playground anakanak, dan aula buat acara-acara bedah buku. Sayangnya cuma wacana dan baru food court yang jadi kenyataan."

"Sayang banget," kata Pange. "Padahal kalau kita bikin mereka tertarik dulu buat ke sini, bukan enggak mungkin mereka betah main ke perpus. Daripada jadiin mal tempat nongkrong, kenapa enggak kita ubah perpus jadi tempat nongkrong?"

Magda memperhatikan sosok pange dalam diam.

"Sori. Ini cuma saran loh, bukan berarti saya bilag perpus ini suram dan jadul. "(Mooseboo, 2019, 195).

Tabel 1.3(Penggambaran makna denotasi dan konotasi)

\begin{tabular}{|l|l|l|}
\hline \multirow{5}{*}{ Denotasi } & Signifier & Signified \\
\cline { 2 - 3 } & $\begin{array}{l}\text { Kutipan dialog halaman 30- } \\
31, \text { dan 195 }\end{array}$ & $\begin{array}{l}\text { Interpretasi / } \\
\text { deskripsi }\end{array}$ \\
\hline \multirow{5}{*}{ Konotasi } & $\begin{array}{l}\text { Signifier } \\
\text { Pustakawan merupakan rekan diskusi } \\
\text { pemustaka dalam beberapa macam ilmu } \\
\text { pengetahuan. }\end{array}$ & $\begin{array}{l}\text { Semustaka } \\
\text { yang datang } \\
\text { penuh rasa } \\
\text { penasaran }\end{array}$ \\
\cline { 2 - 3 } & $\begin{array}{l}\text { Connotative sign: Pustakawan yang menjadi teman diskusi hal- } \\
\text { hal baru bagi pemustaka. }\end{array}$ \\
\hline
\end{tabular}

Pada kutipan dialog halaman 30-31 dan 195 ini, Magda merepresentasikan

pustakwan yang berdiskusi dengan pemustaka yang menanyakan hal-hal yang berhubungan dengan substansi teknologi dan perubahan perpustakaan. Magda sebagai pustakawan mencoba menjelaskan poin-poin yang dimilikinya dalam diskusi tersebut.

Dialog pada halaman 30-31 dibuka dengan pertanyaan yang diajukan Pange sebagai sosok pemustaka terhadap Magda sebagai sosok pustakawan terkait dengan substansi teknologi yang ada dalam benaknya seperti apa. Dengan pengetahuan dan pendapatnya Magda mencoba menyampaikan pandangannya tentang substansi teknologi. Magda sebagai pustakawan menyatakan bahwa teknologi yang bersubstansi menyerupai Perpustakaan Alexandria, dimana hal ini membuka ruang diskusi selanjutnya dikarnakan Pange yang kurang mengetahui tentang Perpustakaan 
Alexandria. Diskusi berlanjut dengan Magda mencoba menjelaskan bahwa perkamenperkamen banyak disimpan di Perpustakaan tersebut, dan menyatakan bahwa teknologi yang bersubstansi merupakan sesuatu yang membawa perubahan.

Pada dialog selanjutnya di halaman 195, dialog dibuka dengan pernyataan dan pertanyaan Pange mengenai mengapa perpustakaan tidak mencoba mengupgrade fasilitasnya seperti membuat game room yang sudah banyak dilakukan oleh perpustakaan lain di luar negeri. Pertanyaan Pange tersebut menuntun Magda pada diskusi mengenai rencana-rencana fasilitas yang akan dilakukan pada pada perpustakaan, yang lalu menjadi diskusi mengenai kemungkinan perpustakaan akan lebih mempunyai banyak peminat apabila dikembangkan mengikuti selera anak muda masa kini. Selain itu dari dialog tersebut dapat dikatakan menungkung representasi suatu diskusi karena adanya tukar pikiran antara tokoh Magda sebagai pustakawan dan Pange sebagai pemustaka.

\section{Kutipan Dialog 4}

"Sebenarnya udah dua bulan ini saya dan tim berencana untuk bikin competitive gaming. Tapi, ada satu kendala dari sisi institusi. Head publisher bilang, kita butuh riset lebih jauhbuat yakinin instansi supaya mereka mau dukung kegiatan ini."

"Terus apa hubungannya dengan saya?"

"Saya butuh kamu buat bantu cari substansinya," jelas Pange mendongak dan mengawasi reaksi Magda di depannya. "I mean semacam data literatur buat bikin analisis persepsi, karena presentasi kemarin menurut saya masih banyak yang bolong dari segi insight, sedangkan untuk ketemu IeSPA dan instansi kita butuh banyak data."

"Kenapa harus saya? Bukannya riset dari konsumen aja udah oke?" tanya Magda.

"Justru itu. Saya mau ada riset dari luar konsumen, dari orang-orang di luar game juga literatur, karena selain kompetisi saya berencana buat seminar atau mungkin talkshow buat tunjukin ke khalayak Industri game itu seperti apa."

"Kenapa game bisa disebut olahraga?" sela Magda.

"Nah, itu dia! Saya minta bantuan kamu untuk ngumpulin pendapat ahli dan riset yang mandang skeptis soal game sama kayak yang tadi kamu bilang," seru Pange mengarahkan telunjuknya ke depan membuat beberapa pengunjung menoleh ke arah mereka. "Setelah saya tahu kenapa mereka ambil kesimpulan kayak gitu, saya bisa cari celah buat ngejelasin."

"Jadi posisi saya sebagai mereka?"

"Exactly! Karena untuk bisa satu frekuensi dengan mereka, kita harus tahu dulu opini dari orang-orang yang sama dengan mereka. Setelah itu baru giliran kita yang selarasin frekuensi biar pelan-pelan mereka bisa terima ide ini." (Mooseboo, 2019, 171-175).

Tabel 1.4(Penggambaran makna denotasi dan konotasi)

\begin{tabular}{|l|l|l|}
\hline \multirow{3}{*}{ Denotasi } & Signifier & Signified \\
\cline { 2 - 3 } & $\begin{array}{l}\text { Kutipan dialog halaman 171- } \\
\text { Interpretasi / } \\
\text { deskripsi }\end{array}$ & \\
\hline \multirow{3}{*}{ Konotasi } & Signifier & \\
\cline { 2 - 3 } & $\begin{array}{l}\text { Pustakawan memberikan bantuan konsultasi } \\
\text { kepada pemustaka secara langsung. }\end{array}$ & $\begin{array}{l}\text { Signified } \\
\text { Pemustaka } \\
\end{array}$ \\
& & $\begin{array}{l}\text { meminta } \\
\text { bantuan, } \\
\text { dengan cara }\end{array}$ \\
\hline
\end{tabular}




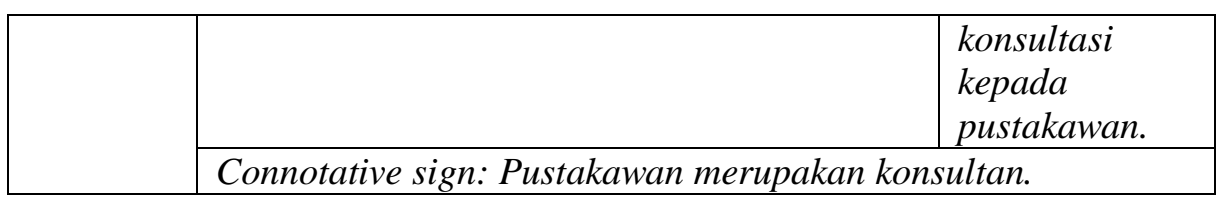

Pada kutipan teks dialog dari halaman 171 hingga 175 ini, merepresentasikan

pustakawan yang secara langsung dimintai bantuan oleh pemustaka sebagai bagian dari responden yang dapat memberikan persepsinya. Dialog juga merepresentasikan vitalnya peran pustakawan dalam hal memberikan konsultasi yang dibutuhkan pemustaka.

Pada dialog halaman 171 hingga 175 tersebut dibuka dengan kalimat yang dilontarkan Pange sebagai pemustaka tentang proyek yang sedang dijalankannya yaitu program competitive gaming. Dimana proyek tersebut membutuhkan data-data tambahan yang dapat diperolehnya dari pustakawan. Dialog berlanjut dengan Magda menanyakan mengapa ia yang berprofesi sebagai pustakawan yang dimintai bantuan oleh Pange dalam melaksanakan proyek yang tengah dilakukannya. Hal ini kemudian berlanjut ke dialog yang menyatakan bahwa Pange mencoba menarik persepsi dari orang lain yang sekiranya tidak berasal dari dunia game dan Magda merupakan salah satu target observasinya. Selain menjadikannya target observasi, Pange juda menjadikan Magda sebagai konsultan dengan pandangan Mmagda sebagai orang awam terhadap game, hal ini direpresentasikan dengan kalimat "Jadi posisi saya sebagai mereka?", yang lantas dijawab Pange dengan menyatakan bahwa untuk melihat apa yang disukai masyarakat yang bukan berasal dari dunia game, maka ia harus meminta nasihat kepada orang-orang yang tidak bermain game, agar menyamakan frekuensi.

\section{Kutipan Dialog 5}

Pange buru-buru berbalik. Dengan wajah tanpa dosa dia beranjak ke sofa dan duduk di sebelah Magda. Tatapan Pange sekatika tertumbuk pada satu titik. Buku..

"Ini... apa?"

"Kemarin kamu minta refrensi kan?," tanya Magdamerogoh kantung sweater panjangnya., menunjukkan sebuah flashdisk di depan wajah Pange. "Dan disini ada beberapa riset dari jurnal yang mungkin bisa kamu pakai."

"Sebentar. Maksud kamu, saya harus baca semua?"

Magda mengangguk mantap. "Masih kurang? Buka laptop kamu, nanti saya kasih akses ke jurnal internasional, siapa tahu kamu butuh. Disana banyak riset soal ini. Atau -"

"Sebentar-sebentar," sahut Pange menginterupsi.

"Ini daftar buku sisanya, kamu cek dulu aja. Beberapa ada yang lagi dipinjam, lainnya saya enggak yakin sesuai, jadi kamu coba lihat dulu," terang Magda memberikan secarik kertas kepada Pange yang mendadak bisu. "Terus ini password wifi siapa tahu kamu butuh buat akses internet."

"Hm," gumam Pange terkesan pasrah.(Mooseboo, 2019, 185-186). 
Tabel 1.5(Penggambaran makna denotasi dan konotasi)

\begin{tabular}{|c|c|c|c|}
\hline \multirow[b]{2}{*}{ Denotasi } & Signifier & Signified & \\
\hline & $\begin{array}{l}\text { Kutipan dialog halaman } 185- \\
186\end{array}$ & $\begin{array}{l}\text { Interpretasi / } \\
\text { deskripsi }\end{array}$ & \\
\hline \multirow{4}{*}{ Konotasi } & \multicolumn{2}{|l|}{ Signifier } & \\
\hline & \multirow{2}{*}{\multicolumn{2}{|c|}{$\begin{array}{l}\text { Pustakawan memberikan informasi berupa } \\
\text { refrensi yang dibutuhkan pemustaka. }\end{array}$}} & Signified \\
\hline & & & $\begin{array}{l}\text { Pemustaka } \\
\text { membutuhkan } \\
\text { bantuan } \\
\text { refrensi dari } \\
\text { pustakawan. }\end{array}$ \\
\hline & \multicolumn{3}{|c|}{$\begin{array}{l}\text { Connotative sign: Pustakawan merupakan fasilitator informasi } \\
\text { dimana pustakawan berperan sebagai agen yang memberikan } \\
\text { informasi, termasuk didalamnya refrensi. }\end{array}$} \\
\hline
\end{tabular}

Pada kutipan dialog halaman 185-186 ini, percapakannya dibuka dengan sosok Pange yang terkejut melihat Magda, yang kemudian melahirkan percakapan dengan Pange bertanya kepada Magda tentang buku-buku yang tadainya dibawa Magda. Hal ini melahirkan dialog selanjutnya dimana Magda mempertanyakan bahwa bukankah Pange memnita untuk dicarikan refrensi oleh Magda yang berprofesi sebagai pustakawan, dan membuat Magda memberikan refrensi berupa buku dan beberapa kumpulan jurnal yang sudah disimpan dalam flashdisk. Dialog berlanjut dengan Pange yang menyatakan akankah ia harus membaca keseluruhan refrensi yang diberikan oleh Magda, dari penggambaran dialognya, tersirat bahwa Pange terkejut akan kemampuan Magda sebagai pustakawan dalam menghimpun informasi. Dialog kemudian berlanjut dengan Magda yang menanyakan apakah refrensi yang diberikannya masih kurang, yang kemudian membuat Magda memberikan akses jurnal internasional kepada Pange. Hal ini menyebabkan Pange panik, yang tergambarkan dalam dialognya. Dialog selanjutnya menggambarkan Magda yang memberikan daftar buku refrensi dalam secarik kertas kepada Pange, dan juga password wifi untuk akses internet. Dalam keseluruhan dialog tersebut, Magda merepresentasikan bagaimana pustakawan mampu memberikan segudang informasi yang dibutuhkan pemustaka, baik dalam bentuk buku ataupun jurnal internasional, yang mana hal ini merepresentasikan profesi pemustaka sebagai fasilitator informasi, dimana hal ini sesuai dengan deskripsinya yaitu tidak hanya menyimpan dan mengelola informasi namun agar informasi tersebut dapat sampai ke tangan pemustaka. 


\section{Representasi Fungsi Perpustakaan}

Penggambaran fungsi perpustakaan dalam novel Beta Testing dapat dilihat pada dialog-dialog yang terjadi antar tokoh dalam novel tersebut. Ada beberapa bagian pada novel yang hanya menampilkan sedikit informasi mengenai fungsi dari perpustakaan itu sendiri. Namun, representasi fungsi perpustakaan yang terlihat paling menonjol dalam dialog-dialog novel ialah pada fungsi perpustakaan sebagai sarana penyimpanan.

\section{Kutipan Dialog 6}

Pange berjalan perlahan menapaki ruangan dengan rak rak tinggi berjejer pada bagian tengah hingga ke belakang. Mungkin sekitar tiga puluh atau bahkan lima puluh rak yang berderet disana. Dia tidak dapat memastikan, lantaran beberapa lampu di area tengah padam, membuat kesan remang-remang. Di area depan, sebuah meja panjang dengan dokumen serta komputer desktop tertata apik, tetapi justru kosong. Sepertinya ditinggal pemiliknya. (Mooseboo, 2019, 12).

"Kalau itu ruangan apa?" tanya Pange dengan dagu menunjuk sebuah ruangan berjendela kaca besar dan gelap.

Magda menarik napas dalam lantaran mulai kesal dengan celotehan-celotehan Pange yang bagonya mirip balita tengah merajuk. "Tempat koleksi Audio Visual. Film dokumenter atau bahan audio visual dari buku seperti kaset, VHS, VCD juga DVD ada di situ."

"Masih pakai VHS?"

"Justru kaset VHS yang seperti itu yang kudu disimpen, dikoleksi dan dijaga. Bukan mentang-mentang sekarang serba digital, yang ketinggalan zaman langsung dibuang gitu aja," terang Magda melirik sebal Pange yang kini duduk pada salah satu kursi di ruang baca. "Tahu kan kalau barang antik lebih mahal?" (Mooseboo, 2019, 101).

Jejeran rak sepanjang ruangan bercat kuning gading, dengan jendela di tiap sisinya menyambut Pange. Beberapa dekstop tersebar di pojok bagian kanan, sementara di bagian kiri Pange melihat ruangan bertuliskan Mini Theater di pintunya. Jauh dari kesan suram. Tatapan Pange lantas kembali menelisik tiap rak yang berisi puluhan atau mungkin ratusan kaset audio visual. Yang langsung memunculkan satu tempat familiar di otak pange.

Rental kaset, $C D$, dan DVD.

"Ayo!" Magda yang baru selesai berdiskusi dan menunjukkan kartu anggotanya pada petugas di meja refrensi, meminta Pange mengikuti. "Tadinya, saya bukan mau ajak kamu ke perpustakaan ini. Kemarin rekan saya bilang, kalau di sini pun masih simpan serial Cosmos, dan tempatnya lebih asyik." (Mooseboo, 2019, 204).

Tabel 1.6(Penggambaran makna denotasi dan konotasi)

\begin{tabular}{|c|c|c|c|}
\hline \multirow[b]{2}{*}{ Denotasi } & Signifier & Signified & \\
\hline & $\begin{array}{l}\text { Kutipan dialog halaman } 12 \text {, } \\
101 \text {, dan } 204 .\end{array}$ & $\begin{array}{l}\text { Interpretasi / } \\
\text { deskripsi }\end{array}$ & \\
\hline \multirow[b]{3}{*}{ Konotasi } & \multicolumn{2}{|l|}{ Signifier } & \\
\hline & \multirow{2}{*}{\multicolumn{2}{|c|}{$\begin{array}{l}\text { Perpustakaan menyimpan koleksi-koleksi, } \\
\text { yang teridiri dari berbagai macam koleksi } \\
\text { yang tidak terbatas jenisnya. }\end{array}$}} & Signified \\
\hline & & & $\begin{array}{l}\text { Beberapa } \\
\text { koleksi langka } \\
\text { yang sudah } \\
\text { sulit diperoleh } \\
\text { banyak yang } \\
\text { masih }\end{array}$ \\
\hline
\end{tabular}




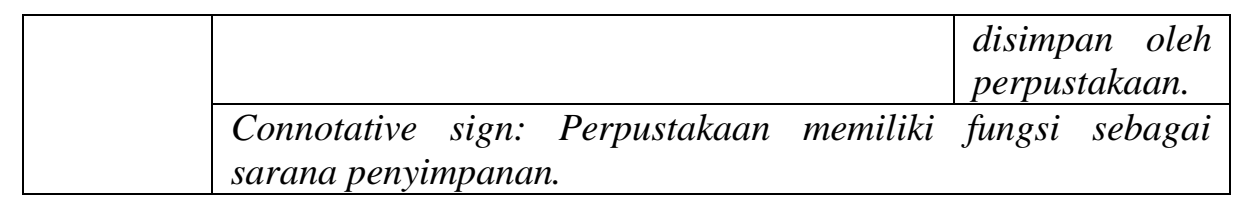

Pada dialog halaman 12, 101, dan 204 tersebut, kalimat dalam dialognya merepresentasikan bagaimana sebuah perpustakaan dapat menyimpan berbagai koleksi. Magda dalam dialognya bersama Pange juga percakapannya dalam dialog, dapat dinilai sebagai suatu representasi terhadap fungsi perpustakaan.

Pada kutipan halaman 10, narasi teksnya menjelaskan bagaimana kondisi perpustakaan yang di dalamnya terdapat berbagai rak buku yang berjumlah sekiat 50 buah, dengan rak yang disusun berjejer. Dalam narasi juga dijelaskan adanya meja informasi dimana terdapat komputer dekstop dan juga dokumen-dokumen. Selanjutnya pada kutipan halaman 101, narasi teksnya yang berupa dialog dibuka dengan sosok Pange yang mengutarakan pertanyaan terhadap sosok Magda akan sebuah ruangan yang berjendela besar namun nampak gelap, yang lalu dijawab Magda dengan menyatakan bahwa ruangan tersebut merupakan ruangan koleksi audio visual dimana ruangan tersebut menyimpan kaset, VHS, VCD, dan DVD. Dialog berlanjut dengan Pange yang menyerukan keterkejutannya atas rasa tidak percaya bahwa perpustakaan masih menyimpan koleksi VHS. Dialog berlanjut dengan Magda yang memberikan penjelasan bahwa benda-benda yang dapat dikatakan langka dan antik, sudah seharusnya disimpan dan dilestarikan karena seiring perkembagan teknologi semakin banyak yang memilih menghanguskan barang-barang langka tersebut.

\section{Kutipan Dialog 7}

Troli penuh buku teronggok di depan koridor bersebelahan dengan ruangan bertuliskan Discussion Room ketika pange melintas.

"Mbak, kalau mau baca enggak harus jadi member, kan?"

Perempuan hitam-putih tadi mengangguk sambil memeriksa formulir yang sudah Pange isi.

"Kalau itu ruangan apa? Boleh saya baca di dalam?"

"Itu ruang diskusi, harusnya sih enggak bisa," terangnya tanpa nada. "Tapi kalau mau pakai, pakai aja. Enggak ada yang pakai juga, kok." (Mooseboo, 2019, 16).

Tabel 1.7(Penggambaran makna denotasi dan konotasi)

\begin{tabular}{|c|c|c|c|}
\hline \multirow[b]{2}{*}{ Denotasi } & Signifier & Signified & \\
\hline & Kutipan dialog halaman 16. & $\begin{array}{l}\text { Interpretasi / } \\
\text { deskripsi }\end{array}$ & \\
\hline \multirow[b]{3}{*}{ Konotasi } & \multicolumn{2}{|l|}{ Signifier } & \\
\hline & \multirow{2}{*}{\multicolumn{2}{|c|}{$\begin{array}{l}\text { Perpustakaan menyediakan ruangan yang } \\
\text { dapat digunakan untuk diskusi pemustaka. }\end{array}$}} & Signified \\
\hline & & & $\begin{array}{l}\text { Ruangan diskusi } \\
\text { di perpustakaan } \\
\text { umumnya tidak }\end{array}$ \\
\hline
\end{tabular}




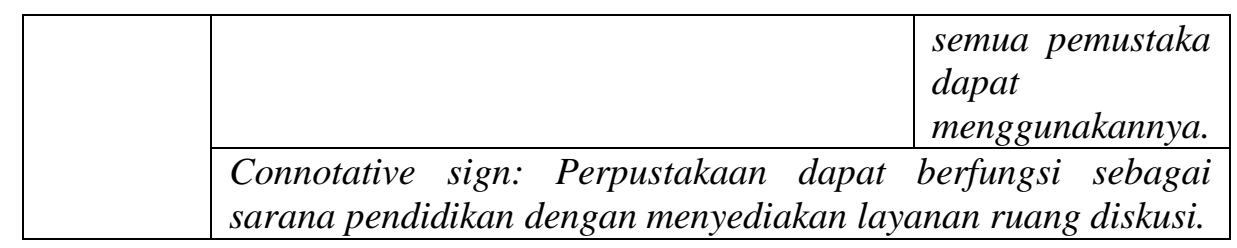

Dalam kutipan narasi dan dialog pada halaman 12 tersebut, dijelaskan bahwa di perpustakaan yang dikelola Magda sebagai pustakawan terdapat ruang diskusi atau Disusion room sebagai bagian dari fasilitas perpustakaan. Dialog pada narasi ini dibuka dengan Pange yang menanyakan apakah dapat menggunakan ruangan diskusi tersebut, yang lalu dijawab Magda, dan diberi penjelasan bahwa sesungguhnya tidak boleh menggunakan ruang diskusi, namun karena sedang tidak adanya pemustaka yang menggunakan maka ruang diskusi boleh digunakan. Dalam narasi ini direpresentasikan adanya ruang diskusi yang dapat digunakan oleh pemustaka. Dalam hal ini, ruang diskusi mampu berperan dalam menunjang fungsi perpustakaan sebagai sarana pendidikan. Pemustaka dapat menggunakan ruang diskusi untuk melakukan diskusi pada masalah pembelajaran, yang mana hal tersebut mampu mendukung fungsi pendidikan.

\section{SIMPULAN}

Dengan pendekatan analisis semiotika Roland Barthes yang telah dilakukan terhadap novel Beta Testing, terlihat sebuah usaha dari sang penulis untuk menggambarkan bagaimana sebuah profesi pustakawan dan bagaimana fungsi suatu perpustakaan sendiri dan bagaimana orang-orang dapat memanfaatkan suatu fungsi dari sebuah perpustakaan. Dalam hasil penelitian ini setidaknya ditemukan ada dua hal yang terjawab. Hal pertama yang ditemukan dan terjawab ialah bagaimana representasi dari profesi pustakawan dikonstrusikan dalam novel Beta Testing dan yang kedua ialah, bagaimana pemaknaan fungsi sebuah perpustakaan direpresentasikan dalam novel Beta Testing. Representasi profesi pustakawan dalam novel Beta Testing sendiri ditemukan lima macam yang dikategorikan sebagai berikut, a) representasi profesi pustakawan sebagai profesi yang berkaitan dengan sebagai penolong (librarian as helper); b) pustakawan yang digambarkan sebagai seorang pendikik (librarian as educator), makna ini muncul dari peranan profesi pustakawan yang mengajarkan atau menjelaskan ilmu yang belum diketahui oleh pemustaka; c) profesi pustakawan yang tergambarkan sebagai seorang teman diskusi (librarian as discussion partner), dimana dijelaskan bahwa pustakawan dan pemustaka keduanya saling bertukar pikiran tentang beberapa objek tertentu; d) pustakawan yang profesinya dimaknakan sebagai seorang 
konsultan (librarian as consultan), dimana pustakawan dapat dimintai pendapatnya dan berperan sebagai konsultan yang memberikan masukan; profesi pustakawan merupakan profesi yang diartikan sebagai seorang fasilitator informasi (information facilitator), dimana dalam representasinya maka pustakawan haruslah mampu menyediakan informasi bagi pemustakanya. Sedangkan sesuai dengan teorinya, fungsi perpustakaan yang ditemukan sebagai sebuah representasi dalam novel Beta Testing ada dua macam, yang dapat dijabarkan sebagai, a) fungsi perpustakaan digambarkan melalui kalimat-kalimat yang dituangkan dalam narasi. Perpustakaan direpresentasikan sebagai sebuah sarana penyimpanan koleksi; dan b) perpustakaan dibentuk dan direpresentasikan sebagai suatu sarana pendidikan. Dimana makna ini ini muncul melalui peranan pustakawan dan juga penggunaan perpustakaan oleh pemustaka sendiri.

\section{DAFTAR PUSTAKA}

Devi, Katrin Setio., \& Subekti, Slamet. (2016).Proyeksi Pemustaka Terhadap Seterotype Perpustakaan dalam Fanfiction.Jurnal Ilmu Perpustakaan, vol5(2). http://ejournal3.undip.ac.id/index.php/jip/article/view/15307

Hall, Stuart. (2003). "The Work of Representation”, Representation : Cultural Representation and Signifying Practices. London: Sage Publication.

Hasugian, Jonner. (2009). Dasar-dasar Ilmu Perpustakaan dan Informasi. Medan: USU Press.

Heriyanto, dkk. (2013). Makna dan Penghayatan Profesi Pustakawan Studi Fenomenologis Terhadap Para Pustakawan pada Perpustakaan Perguruan Tinggi. Jurnal Kajian $\begin{array}{lllll}\text { Informasi \& Perpustakaan, } & \text { vol. } & 1(2), & 147-156 .\end{array}$ https://doi.org/10.24198/jkip.V1I2.11004

Kriyantono, Rachmat. (2012). Teknik Praktis Riset Komunikasi. Jakarta: Kencana Prenada Media Grup.

Mayesti, Nina, dkk. (2018).Stereotip Pustakawan Perempuan dalam Film Indonesia Era 2000-an. Record and Library Journal, vol.4(1), 15-21. http://dx.doi.org/10.20473/rlj.V4-I1.2018.15-21

Moosebo. (2019). Beta Testing. Jakarta: PT. Elex Media Komputindo.

Morissan. (2013). Teori Komunikasi; Individu Hingga Massa. Jakarta: Kencana Prenada Media Grup.

Qalyubi, Syihabuddin. (2007). Dasar-dasar Ilmu Perpustakaan dan Informasi. Yogyakarta : Jurusan Ilmu Perpustakaan dan Informasi Fakultas Adab.

Trimo, Soejono. (1992).Pedoman Pelaksanaan Perpustakaan. Bandung : Remaja Rosdakarya. 